\title{
Hair cell regeneration: An exciting phenomenon ... But will restoring hearing and balance be possible?
}

\author{
Jonathan I. Matsui, PhD; ${ }^{1-2 *}$ Brenda M. Ryals, $\mathbf{P h D}^{3}$ \\ ${ }^{1}$ Department of Molecular and Cellular Biology, Harvard University, Cambridge, $M A ;{ }^{2}$ Laboratory for Cellular \\ and Molecular Hearing Research, Department of Otolaryngology, Children's Hospital, Boston, MA; ${ }^{3}$ Department \\ of Communication Sciences and Disorders, James Madison University, Harrisonburg, VA
}

\begin{abstract}
Sensory hair cells of the inner ear are susceptible to damage from a variety of sources including aging, genetic defects, and environmental stresses such as loud noises or chemotherapeutic drugs. Unfortunately, the consequence of this damage in humans is often permanent hearing/balance problems. The discovery that hair cells can regenerate in birds and other nonmammalian vertebrates has fueled a wide range of studies that are designed to find ways of restoring hearing and balance after such damage. In this review, we will discuss some of the key recent findings in sensory hair cell regeneration and what they mean for audiologists and other hearing healthcare practitioners.
\end{abstract}

Key words: audiology, auditory, genomics, hair cells, hearing, regeneration, stem cells, supporting cells, vestibular.

\section{INTRODUCTION}

The auditory and vestibular systems are two complex sensory systems in the inner ear that help us regulate our hearing and balance. Hair cells are the mechanoreceptors in the inner ear that detect sound, head movement, and orientation in space. Aging, genetic defects, and environmental stresses such as loud noises or exposure to chemotherapeutic drugs (e.g., cisplatin, aminoglycoside antibiotics) can lead to significant hearing and balance deficits in humans due to loss of or damage to these cells. Researchers have proposed regenerating these sensory cells as a means of restoring hearing and balance in humans. Scientists once believed that warm-blooded animals had a full complement of hair cells at birth, and when they were lost, the loss was permanent. In the late 1980s, however, several studies demonstrated that birds could regenerate their sensory hair cells [1-4]. More importantly, other studies demonstrated that the regenerated sensory hair cells were functional [5-6]. Fifteen years later, the regeneration phenomenon is better understood, but the signaling mechanisms that regulate hair cell regeneration remain unknown. This review will discuss some of the latest findings and techniques of the study of hair cell regeneration and what they mean for audiologists.

\footnotetext{
Abbreviations: EGF = epidermal growth factor, Math1 = mammalian atonal homolog 1 , TGF- $\alpha=$ Transforming growth factor $\alpha$.

This material was based on work supported by the National Organization for Hearing Research Foundation, the National Institutes of Health Individual NRSA Fellowship (grant EY14790), and the National Institutes of Health, National Institute on Deafness and Other Communication Disorders (grant RO1 DC001372).

*Address all correspondence to Jonathan I. Matsui, PhD; The Biological Laboratories, Harvard University, 16 Divinity Avenue, Cambridge, MA 02138; 617-495-2599; fax: 617-4963321. Email: jmatsui@fas.harvard.edu

DOI: 10.1682/JRRD.2005.01.0008
} 
JRRD, Volume 42, Number 4, 2005, Supplement 2

The sensory epithelium of the inner ear is composed of two different general cell types: sensory hair cells and nonsensory supporting cells (Figure 1). There are several types of sensory hair cells in the mammalian inner ear, depending on whether you are examining the auditory system (inner and outer hair cells) or the vestibular system (type 1 and 2 hair cells), which can be distinguished by their location in the organ, their different morphologies, and the type of neurons that innervate them. There are also different types of supporting cells found within the mammalian auditory system (e.g., Deiters' cells, pillar cells). Scientists have yet to find morphological, molecular, or physiological differences between the different types of supporting cells in the vestibular system. One major difference between the two sensory systems is that the hair cells in the mammalian auditory system do not regenerate, whereas the hair cells in the vestibular system of both mammalian and nonmammalian species exhibit a low level of regeneration [7-8].

Many events occur when hair cells in the inner ear are damaged or killed. For instance, when hair cells in the sensory epithelium are damaged with a sublethal stimulus, data from amphibians and mammals suggest the sensory epithelium repairs itself [9-11]. Dying hair cells undergo a form of cell death called apoptosis [12-13] and are either ejected from the sensory epithelia [14] or engulfed by neighboring cells. Following the death of the hair cells, neurons from the auditory nerve retract. When hair cell damage or death occurs in birds, some signal from the dying hair cell triggers the neighboring supporting cells to either proliferate or transdifferentiate into immature hair cells. The cells then need environmental, molecular, or genetic cues to differentiate into hair cells. Finally, nerve fibers from the auditory nerve reconnect the hair cells to the central nervous system so the bird can process the sensory information. Unlike birds, proliferation or transdifferentiation of supporting cells into hair cells does not occur spontaneously in mammals after hair cell death or damage.

\section{SUPPORTING CELL PROLIFERATION OR TRANSDIFFERENTIATION: WHICH IS THE BEST WAY TO POPULATE THE SENSORY EPITHELIUM?}

Over the past 15 years, two different mechanisms have been proposed for sensory hair cell regeneration in avian and other nonmammalian species (Figure 2). Many
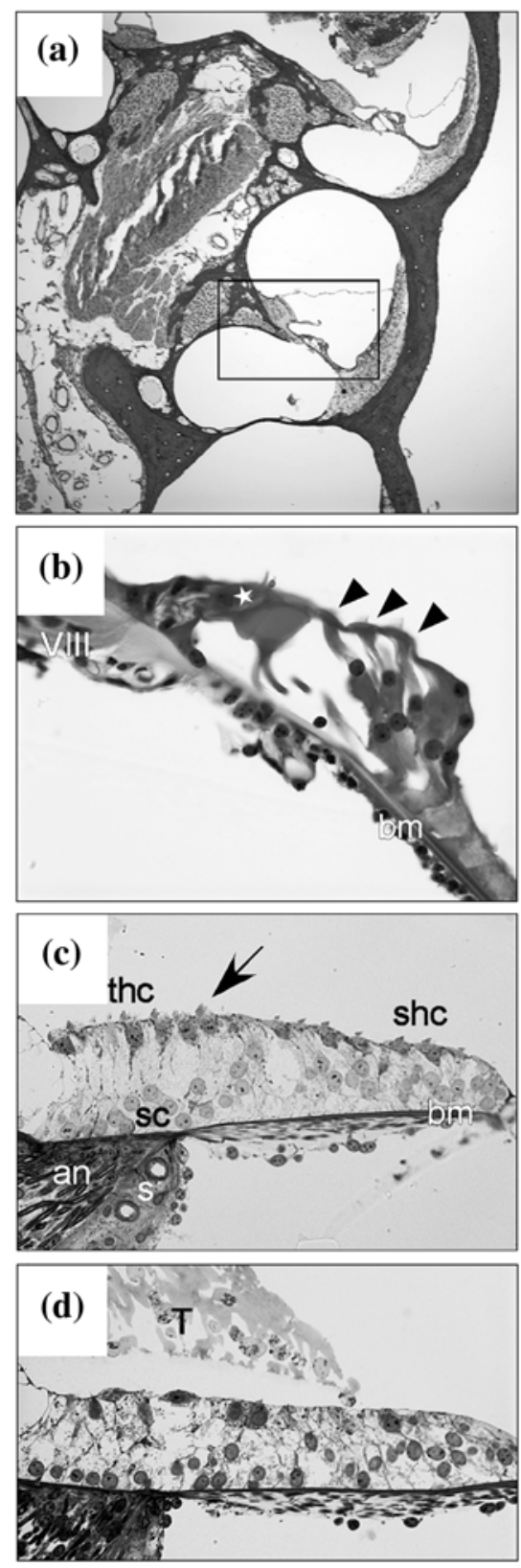

Figure 1.

Cellular architecture of organ of Corti in guinea pig cochlea and chicken basilar papilla. (a) Light microscopy of cross-section of middle and upper turn of adult guinea pig cochlea. (b) Higher magnification of middle turn of cochlea (box in (a)) with 3 outer hair cells (arrow heads), inner hair cell ( ), VIIIth cranial nerve (VIII), and basilar membrane (bm) shown. Sensory epithelium from (c) undamaged and (d) gentamicin-damaged basilar papilla is shown. bm separates stroma(s), which contains auditory nerve (an), from supporting cells (sc) that span entire sensory epithelium and have basally located nuclei. Tall hair cells (thc) occur on superior region and short hair cells (shc) reside on inferior region of organ. Both types of hair cells reside near lumenal surface; have apical stereocilia (arrow), which abuts tectorial (T) membrane; and have nuclei located toward lumen. Gentamicin-treated hair cells have pyknotic nuclei. 
(a)

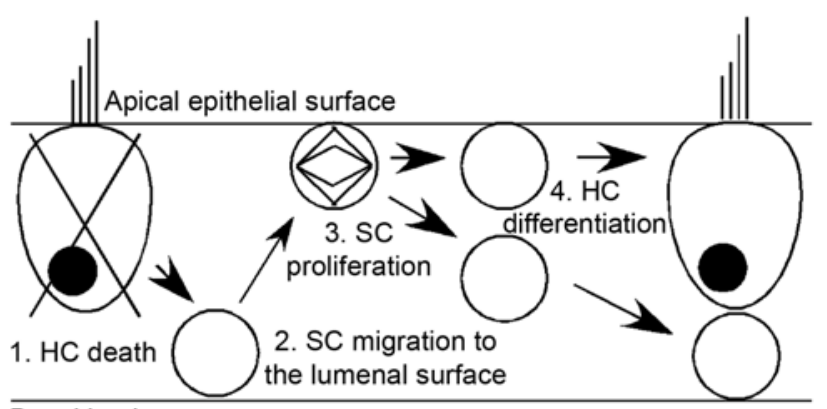

Basal lamina

(b)

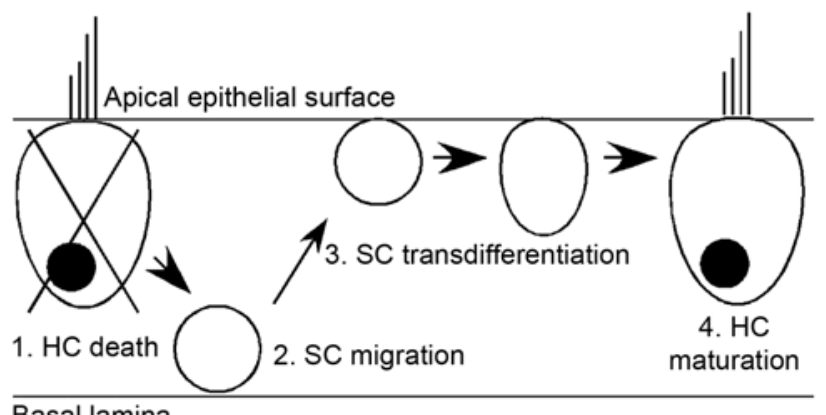

Basal lamina

Figure 2.

Proposed mechanisms of how sensory hair cells (HCs) may regenerate from supporting cells (SCs). (a) Schematic of how HCs regenerate via mitosis (cell proliferation). Dying HC sends out signal for SCs to proliferate and then differentiate into HC or SC. (b) Schematic of how SCs transdifferentiate into HCs. Models are consistent with present data, but our knowledge of details of these processes is still rudimentary.

studies indicate that the supporting cells adjacent to the dying hair cell receive a signal that activates them, such as when the extracellular-matrix connection between hair cells and supporting cells is broken [15]. The supporting cells then migrate through the sensory epithelium and regenerate by cell division (i.e., mitosis) [7,16-50]. During mitosis, one or more daughter hair cells are generated either through symmetrical differentiation, which produces two hair cells or two supporting cells [18,24,41], or asymmetrical differentiation that produces one hair cell and one supporting cell (Figure 2(a)) [27,31,38,41]. Alternatively, hair cells might convert or transdifferentiate from neighboring supporting cells through nonmitotic mechanisms (Figure 2(b)) [33,51-55]. Transdifferentiation is defined as an alteration of gene expression in a particular cell that changes the fate of the cell. Traditionally, mitotic transdifferentiation has been termed "regeneration," and the conversion of a supporting cell to a hair cell through nonmitotic means has been termed "transdifferentiation.” Although the transdifferentiation of supporting cells through nonmitotic means may seem to be a simpler way of replacing dead hair cells than stimulating local cells to reenter the cell cycle, such nonmitotic sensory cell replacement could significantly alter the structural integrity of the sensory organ. For example, if local, resident supporting cells transdifferentiated into hair cells, without replacing themselves, then the mechanical structure of the organ of Corti could be compromised. On the other hand, if nonresident cells within the sensory organ could transdifferentiate into hair cells and migrate to the appropriate position to replace lost hair cells then this nonmitotic mechanism could be quite effective. Although all nonmammalian vertebrates regenerate hair cells, two critical questions remain unanswered: Why have only mammalian vestibular hair cells shown any capacity for regeneration? Why are hair cells in the auditory portion of the inner ear apparently unable to regenerate after damage? As previously mentioned, the supporting cells in the mammalian cochlea undergo terminal mitosis during embryogenesis, but the supporting cells in the mature mammalian vestibular system retain some limited capacity to regenerate [7-8]. Several different approaches have been taken since the discovery of avian hair cell regeneration to induce these normally quiescent supporting cells in the auditory portion of the mammalian inner ear to regenerate. The most successful approaches include the use of growth factors, stem cells, and the manipulation of specific genes. These approaches are discussed in the following.

\section{MOLECULAR AND GENETIC APPROACHES TO STUDYING HAIR CELL REGENERATION}

\section{Growth Factors and Immune Response Following Trauma}

When hair cells are killed or the sensory epithelium is traumatized, macrophages and other leukocytes are recruited to the damaged region within hours of the trauma [56]. Macrophages are a type of leukocyte, or white blood cell, that are sometimes recruited to sites of injured tissue and may be involved in initiating wound healing and repair [57]. Resident macrophages recognize and destroy dying cells by engulfing them [58] and many secrete substances that may influence cell function [59]. Although the functional role of macrophages in the inner ear is unknown, numerous studies have demonstrated that macrophages and leukocytes reside in the undamaged sensory epithelia of the inner ear and are recruited to 
traumatized areas prior to the initiation of supporting cell proliferation [31,45,56,60-65].

Some scientists have hypothesized that macrophages and other leukocytes produce growth factors or cytokines that may trigger hair cell regeneration. Growth factors are substances that promote cellular growth and survival. Some growth factors are also known mitogens that promote proliferation through cell division. Investigators have used growth factors, either individually or in combination, to determine if they can promote mitotic regeneration. The most commonly cited growth factors used to promote hair cell regeneration include fibroblast growth factor, insulin-growth factor, brain-derived neurotrophic factor, epidermal growth factor (EGF), and transforming growth factor $\alpha$ (TGF- $\alpha$ ) [6]. Some of these growth factors have had limited success in stimulating supporting cell proliferation in the mature mammalian sensory epithelia. For instance, a cocktail containing TGF- $\alpha$, insulin, and the mitotic tracer tritiated-thymidine was infused into the inner ears of rats to determine if the growth factor could stimulate the supporting cells to divide and produce differentiated postmitotic hair cells [50]. Tritiated-thymidine is one of the building blocks or bases that make up DNA and is incorporated into dividing cells where it can be detected with the use of autoradiography. Thus, the investigators could evaluate through autoradiography whether infusion of the drug cocktail resulted in new, mitotically generated hair cells. These investigators found that new hair cells were generated in situ by means of a mitotic mechanism in adult mammals (some hair cells had incorporated the tritiated-thymidine), but only a small subset of the supporting cells retained an intrinsic capability to proliferate. This study suggests that while these growth factors may be able to stimulate some supporting cells to mitotically transdifferentiate into hair cells, they could not stimulate the full regenerative capacity of all of the supporting cells within the inner ear.

\section{Stem Cells}

Recently, the use of stem cells to repair damaged neurons or prevent degenerative diseases has been a high-profile topic in the news media. Stem cells are a type of cell with the capacity to self-renew and differentiate into a variety of cell types. Different types of stem cells have been identified in mature mammals [66]. Supporting cells found in the mammalian vestibular system, but not in the auditory system, have the capacity to selfrenew and differentiate into hair cells. But since growth factors have not stimulated significant numbers of sup- porting cells to proliferate in the mature mammalian inner ear, one critical question needs to be addressed: Are supporting cells in the mammalian sensory epithelia actually stem cells? When cells are isolated from the sensory epithelia of the adult mouse utricle (a vestibular organ), they produce proliferating cellular spheres [67]. These spheres self-renew and produce cell types with the morphological characteristics and biological markers of hair cells (e.g., myosin VIIA and Brn-3.1) and supporting cells [e.g., p27(kip1)] [67]. Therefore, in light of current cell biology definitions, some scientists may classify the utricular supporting cells as stem cells. Many other questions remain about the use of stem cells. For instance, since the supporting cells in the normal mouse utricle proliferate at a very low level, what are the molecular and environmental cues that make activation of these cells possible when isolated in culture? More importantly, will activation of these cells be possible in vivo?

Another potential source of stem cells is embryonic animals. Recently, mouse embryonic stem cells were implanted into chicken embryos, where they matured and were integrated into the inner-ear's sensory patches [68]. Moreover, when fetal-mouse neural stem cells were transplanted into the mouse inner ear after drug-induced injury, some of the grafted cells differentiated into glial or neural cells while other cells integrated into the vestibular sensory epithelia and expressed hair cell markers [69]. It is not clear whether the newly generated cells formed the neural connections necessary to restore hearing and balance.

\section{Genetic Controls Regulating Supporting Cell Proliferation}

The supporting cells in the auditory system undergo terminal mitosis during embryogenesis [7-8]. Specific genes may play a role in supporting cell proliferation and hair cell development: a fact that may eventually be applied to hair cell regeneration studies. For instance, correct timing of the end of the cell cycle in the developing organ of Corti requires a cyclin-dependent kinase inhibitor called p27(Kip1). p27(Kip1) inhibits the progression of the cell cycle. When the p27(Kip1) gene is "knocked out" in mice, it results in ongoing supporting cell proliferation in the embryonic and mature organ of Corti well after mitosis in the sensory epithelia normally ceases [70-71]. Moreover, there are supernumerary hair cells and supporting cells in the organ of Corti [70]. Mice that have had the p27(Kip1) gene knocked out never hear normally (more hair cells does not necessarily mean better hearing) and die prematurely. The presence of p27(Kip1) is critical to 
limiting the number of hair cells produced; when it is not present, hair cell number increases. Therefore, if this information is used for future therapies, we will need to understand how to manipulate this inhibitory gene to initiate the cell cycle and also to regulate the number of hair cells produced.

\section{Mammalian Atonal Homolog 1}

Once supporting cells in the ear are induced to proliferate, other signals are needed to differentiate the proliferating cells into hair cells. One particular signal mammalian atonal homolog 1 (Math1) has received a lot of attention recently since it is required for hair cells to differentiate [72-73]. In developing animals, hair cells express Math1, while nonsensory supporting cells do not. Genetically altered mice deficient in Math1 fail to develop both sensory hair cells and supporting cells [72-73]. Moreover, supernumerary hair cells are generated when Math1 is overexpressed in mouse ear cultures [74]. Math1 determines cell fate within the cochlea. When Math1 is present in the cochlea, some cells become hair cells and have the morphologic and genetic attributes of mechanosensory hair cells; when it is absent, they do not.

One way of manipulating gene expression within cells is to use viruses. Scientists have used virally mediated vectors (i.e., adenovirus and herpes simplex virus) to efficiently transfer specific genes, such as growth factors or transcription factors, into hair and supporting cells [7589]. Several adverse side effects to the use of adenoviruses in transgenetic expression that can limit their use include cytotoxicity, immune responses, nonspecific infection, and damage to hair cells, [85,90]. When the mature guinea pig ear is inoculated with an adenovirus that over expresses Math1 via the endolymph, the over expression of Math1 is found in the organ of Corti in nonsensory cochlear cells and immature hair cells [91]. The interpretation of this is that nonsensory cells within the scala media have received the Math1 "signal" to change their fate and become hair cells. In this study, axons extended from the auditory nerve toward the newly generated hair cells, which suggests that the new cells attracted the neurons. Therefore, we now have evidence that nonsensory cells in the mature mammalian cochlea may retain the ability to generate new hair cells and that Math1 is sufficient to direct these cells to differentiate into hair cells. One recent study supports the conclusion that nonsensory cells in the mammalian cochlea retain the capacity to become hair cells if given the appropriate local environment and genetic cues. These researchers established a dissociated cell culture system in which sensory hair cells and supporting cells were generated from resident nonsensory cells [92]. They incorporated a Math1-green fluorescent protein transgene, which is expressed exclusively in hair cells, so that the hair cells would be easily detected with a fluorescent microscope, and they determined that EGF and periotic mesenchymal cells were required for the growth and differentiation of hair cells in culture. The periotic mesenchyme consists of mostly undifferentiated mesoderm that surrounds the ear and that, under normal circumstances, gives rise to a variety of structures and cell types including connective tissues, blood, bone, and cartilage.

\section{Genomics}

Investigators have started using microarrays to identify specific genes whose roles promote cell proliferation and differentiation in the inner ear [93]. Microarrays are used to survey the expression of thousands of genes that are likely to be expressed in a particular tissue at a particular time under a particular set of conditions. The arrays consist of a large number of fragments of genes (e.g., complementary DNAs or oligonucleotides) that are immobilized on the surface of a glass chip or other surface such as plastic or silicone. Once the "chip" is constructed, the target messenger RNA that is taken from the tissue of interest under specific conditions is labeled with a fluorescent dye and then placed on the chip, which is scanned with a laser. The intensity of the signal produced by 1,000 molecules of a particular labeled transcript should be twice as bright as the signal produced by 500 molecules. Therefore, scientists can measure the expression pattern of many genes in a particular sample simultaneously and determine if a particular gene is turned "on" or "off."

Microarray analysis has been used to study inner-ear genes in mice, rats, and chicks [94-97]. To gain insights into the genetic programs that govern the regenerative capacity of hair cells, researchers have compared gene expression profiles of sensory epithelia taken from chick utricles and basilar papillae (cochlea) [97]. One important assay during microarray analysis is determination of the presence of transcription factors-proteins that are required to initiate or regulate gene transcription or activity. Of the many genes screened, about 600 transcriptionfactor genes are active to some degree in both vestibular and auditory end organs. Interestingly, about 40 transcription factors are active in one but not the other end organ. These differences in the presence of genetic transcription 
factors may be helpful in identifying fundamental differences between the normally quiescent auditory sensory epithelium and the mitotically active vestibular sensory epithelium. Although many genes have been identified using this approach, it does not guarantee that the genetically controlled proteins are produced or functional. If, however, a difference in transcript abundance is observed between two or more conditions, it is natural to infer that the difference might point to an interesting biological phenomenon. Therefore, scientists have only begun to determine what role these genes play in regulating hair cell development and regeneration.

\section{FUNCTIONAL STUDIES EXAMINE COMPLEX BEHAVIORS}

Once scientists discovered that birds could regenerate their sensory hair cells, the next logical question was, “Are the regenerated cells functional?” Not only do the supporting cells need to differentiate into hair cells, but the newly differentiated hair cells also need to grow stereocilia bundles, form appropriate ion channels for transduction, and be reinnervated by the auditory nerve fibers to connect the sensory receptor to the central nervous system. The animals must also be able to access the new sensory information and use it to make behaviorally meaningful responses. Two well-written reviews that cover functional recovery following sound- and druginduced damage have been published [5-6].

Although numerous studies have examined the physiology of recovered sensory hair cells, few studies have examined the complex properties of perceptual processing and behavioral plasticity after hair cell regeneration. Compensatory behaviors such as oculomotor, gaze, and postural responses that occur during movement largely depend upon a functioning vestibular system. The vestibular ocular reflex and the vestibular colic reflex disappear after hair cells in the crista of the semicircular canals are killed with aminoglycoside antibiotics [98-103]. These reflexes, however, reappear as the hair cells regenerate [99-102,104]. More recently, Dickman and Lim trained adult pigeons to run along a long chamber and peck an illuminated key to receive a fluid reward [105]. Multiple behavioral measures for assessment of performance, posture, and head stability were quantified. Once normative values were obtained, the animals received aminoglycoside antibiotics that killed the sensory hair cells in the vestibular system, which resulted in severe postural and head instability. As the regeneration process progressed, the tremors and head shakes diminished and spatial orientation and navigation ability improved to pretreatment levels.

In the auditory system, recognition and production of vocal signals depend on hearing and are necessary for communication. Dooling and his colleagues used budgerigars (Melopsittacus undulatus [Australian parrot]) to examine the return of complex auditory perception and vocal production after hair cell regeneration [106-107]. Budgerigars mimic sounds and readily learn new vocalizations throughout their lives, which has been likened to language acquisition in humans. The birds were trained to precisely match their vocalizations to specific acoustic templates. Aminoglycoside antibiotic treatment induced a high-frequency hearing loss, which disrupted both auditory perception and vocal production. Behavioral tests of auditory sensitivity showed that audiometric thresholds returned to near (within $20 \mathrm{~dB}$ ) normal levels within 4 weeks. Difference thresholds for frequency and intensity returned to normal levels as well. More complex perceptual tasks, such as vocal call discrimination/recognition, took much longer (up to 5 months) but returned to normal levels after hair cell regeneration. Precision in vocal production initially declined but was restored to pretreatment levels well before the full recovery of auditory function. These data suggested that relatively little acoustic feedback from a few regenerated hair cells was necessary to effect full recovery of vocal precision. These results may have particular relevance for understanding the relationship between hearing loss and human speech production especially where an auditory prosthetic device, such as a cochlear implant, is being considered.

Woolley and her colleagues conducted another series of studies that examined complex communication behavior in Bengalese finches [108-111]. Male Bengalese finches are songbirds that learn a single sequence of "syllables" early in life and reliably produce the same song throughout their lives. After recording each animal's song and verifying its stability, researchers treated the birds with a combination of sound exposure and aminoglycoside antibiotics to cause hearing loss, and the songs rapidly deteriorated [112]. As hearing was restored by hair cell regeneration, which was assessed by auditory brainstem responses [109], the song returned to its preexposure structure [110]. Restoration of hearing allowed each bird to access a stored "template" of its own learned vocalization and gradually match its new vocalizations to this stored memory. 


\section{SUMMARY AND CONCLUSIONS}

The hair cell regeneration phenomenon has been well documented in nonmammalian species. We are just beginning to see the fruits of our efforts to induce hair cell regeneration in the mammalian cochlea. While inherent genetic inhibitory controls prohibit spontaneous hair cell regeneration in mammals, recent discoveries suggest that the use of externally introduced factors and/or stem cells may override this inhibition. Advances in genomics, adenovirus gene therapy, and stem cell technology have raised hope that perhaps a cure for sensorineural hearing loss will be found. A safe and effective means of delivering genes and/or stem cells needs to be developed for these therapies to be of any clinical relevance. Moreover, being able to direct stem cells and adenoviruses to the correct locations for promotion of supporting cell proliferation followed by hair cell differentiation is paramount to the return of function. Future studies of the molecular and genetic mechanisms of hair cell regeneration in mammals are likely to focus on these important issues. Finally, the impact of induced hair cell regeneration on neural connections and the brain will need to be understood in order for researchers to predict the ultimate impact of mammalian hair cell regeneration on the restoration of the complex mechanisms that are involved in hearing and understanding human speech.

This review article has addressed the current state of basic science in regard to the status of hair cell regeneration in mammals. While this information is vital to initiating some form of therapeutic advance, it is relatively far removed from everyday clinical practice. Nevertheless, forward-thinking clinicians have questions about the impact of future therapies on their clinical practice. Significant among these questions are: When will hair cell regeneration be a reality for patients? What will the measures of candidacy be? What will the impact of hair cell regeneration be in patients who are or have been candidates for hearing aids or other amplification devices? Will hearing aids or cochlear implants continue to be necessary in the face of hair cell regeneration?

The first of these questions, what is the time frame for human hair cell regeneration therapy, has been asked since the first papers on hair cell regeneration were published in 1988. The answer to the question then was that we have to discover whether the possibility to regenerate hair cells in any mammal exists before we can address issues of human therapy. We now know that it is possible to regenerate hair cells and many other cells in the inner ear of mature mammals, at least to a limited extent. This is a huge step forward, but not large enough for us to begin regenerating hair cells in humans. The next important question to be answered is this: Is mammalian hair cell regeneration sufficiently safe and robust enough to restore hearing and balance function? The fact that regeneration of avian hair cells results in the restoration of hearing sensitivity, complex perception, and vestibular function is promising for the future potential of hair cell regeneration for restoring hearing and balance function in mammals.

The question of candidacy for hair cell regeneration therapy must be considered in light of our understanding of the mechanisms of hair cell regeneration. Hair cell regeneration occurs spontaneously in birds immediately after damage and cell loss. Therefore, research in birds has done little to increase our understanding of the effects of hair cell regeneration on the restoration of hearing in the face of long-term hair cell damage and hearing loss. So, we can say little about the influence of the duration of hearing loss or cochlear damage on candidacy for hair cell regeneration treatments. However, since our experience with cochlear implantation in adults with longstanding hearing loss has been positive, it seems likely that duration of hair cell loss will not obviate potential treatment with hair cell regeneration.

Studies of hair cell regeneration in Belgian Waterslager canaries with genetic, progressive deafness [113114] show that hair cell regeneration neither fully restores the number of hair cells nor restores hearing. In this species, the genetic disorder appears to be localized to the hair cells themselves; the auditory nerve fibers are minimally affected [115-116]. Therefore, hair cell regeneration may not be a viable therapy in mammals or humans with genetic abnormalities at the level of the hair cell. More research on the influence of existing genetic abnormalities on hair cell regeneration is needed to more fully answer questions of candidacy in patients with genetic inner-ear abnormalities.

Once regeneration has been stimulated in birds, other structures within the ear also appear to repair themselves [117]. Recent evidence in mature mammals has shown that stem cells have the potential to regenerate several cell types within the cochlea $[13,118]$. It is certain that the regeneration of more than one cell type, such as both hair cells and supporting cells, will be more complex than the regeneration of a single cell type. This is particularly true if cell differentiation is primarily guided by 
genetic cues as opposed to local environmental cues. Therefore, it will be essential to understand the structural integrity of the cochlea prior to treatment with regenerative therapy. Research on the structural consequences of inner-ear diseases and toxins will be critical to this endeavor. The prognosis for restoring hearing through hair cell regeneration will certainly be influenced by the inherent structural integrity of the cochlea. However, based on what we have learned from cochlear implant research, it seems likely that damage to cells other than hair cells will not necessarily preclude the possibility of treatment with regenerative therapy.

Finally, some clinicians have questioned the impact of future regenerative therapies on their patients who have been treated with amplification devices or cochlear implants. Will hair cell regeneration eliminate the need for hearing aids and cochlear implants? The short answer to this question is "No." Hair cell regenerative therapies are unlikely to restore full function to the cochlea. If the potential for safe initiation of hair cell regeneration in humans does become a possibility, the first attempts will probably result in incomplete replacement of all structures necessary for normal hearing. Even this incomplete replacement, however, could be very good news for both audiologists and patients with sensorineural hearing loss. Patients who have such severe hearing losses (very severe to profound corner audiograms, or severe to profound sharply sloping high-frequency hearing loss) that they are difficult to fit with hearing aids could benefit greatly from the restoration of just a few hair cells. The addition of a few hair cells that are connected to the appropriate neural fibers might increase sensitivity to the point where amplification could be useful. Therefore, hair cell regeneration therapy might increase the number of patients who benefit from amplification. We predict that restoration of some outer hair cells might result in an ear with better tuning and less loudness distortion for those with less severe hearing loss but with unsatisfactory results from hearing aids.

It seems hard to imagine that improved medical treatment of sensorineural hearing loss, through therapies such as hair cell regeneration, could be anything but positive for audiologists and the patients whom they treat. Further research into the basic cellular, molecular, and genetic mechanisms of hair cell regeneration is always done with an eye for transferring the results into clinical practice and can only have positive potential outcomes for veterans and all patients with permanent sensorineural hearing loss.

\section{ACKNOWLEDGMENTS}

We would like to thank Dr. Douglas Cotanche for his helpful advice when preparing this manuscript. We would also like to thank Dr. Mark Parker for providing the guinea pig section to photograph.

\section{REFERENCES}

1. Cotanche DA. Regeneration of hair cell stereociliary bundles in the chick cochlea following severe acoustic trauma. Hear Res. 1987;30(2-3):181-95.

2. Cruz RM, Lambert PR, Rubel EW. Light microscopic evidence of hair cell regeneration after gentamicin toxicity in chick cochlea. Arch Otolaryngol Head Neck Surg. 1987;113(10):1058-62.

3. Corwin JT, Cotanche DA. Regeneration of sensory hair cells after acoustic trauma. Science. 1988;240(4860):1772-74.

4. Ryals BM, Rubel EW. Hair cell regeneration after acoustic trauma in adult Coturnix quail. Science. 1988;240(4860): 1774-76.

5. Smolders JW. Functional recovery in the avian ear after hair cell regeneration. Audiol Neurootol. 1999;4(6):286-302.

6. Bermingham-McDonogh O, Rubel EW. Hair cell regeneration: winging our way towards a sound future. Curr Opin Neurobiol. 2003;13(1):119-26.

7. Warchol ME, Lambert PR, Goldstein BJ, Forge A, Corwin JT. Regenerative proliferation in inner ear sensory epithelia from adult guinea pigs and humans. Science. 1993;259(5101):1619-22.

8. Rubel EW, Dew LA, Roberson DW. Mammalian vestibular hair cell regeneration. Science. 1995;267(5198):701-7.

9. Sobkowicz HM, August BK, Slapnick SM. Cellular interactions as a response to injury in the organ of Corti in culture. Int J Dev Neurosci. 1997;15(4-5):463-85.

10. Zheng JL, Keller G, Gao WQ. Immunocytochemical and morphological evidence for intracellular self-repair as an important contributor to mammalian hair cell recovery. J Neurosci. 1999;19(6):2161-70.

11. Gale JE, Meyers JR, Periasamy A, Corwin JT. Survival of bundleless hair cells and subsequent bundle replacement in the bullfrog's saccule. J Neurobiol. 2002;50(2):81-92.

12. Forge A, Li L. Apoptotic death of hair cells in mammalian vestibular sensory epithelia. Hear Res. 2000;139(1-2): 97-115.

13. Matsui JI, Cotanche DA. Sensory hair cell death and regeneration: two halves of the same equation. Curr Opin Otolaryngol Head Neck Surg. 2004;12(5):418-25.

14. Mangiardi DA, McLaughlin-Williamson K, May KE, Messana EP, Mountain DC, Cotanche DA. Progression of hair cell ejection and molecular markers of apoptosis in 
the avian cochlea following gentamicin treatment. J Comp Neurol. 2004;475(1):1-18.

15. Warchol ME. Cell density and N-cadherin interactions regulate cell proliferation in the sensory epithelia of the inner ear. J Neurosci. 2002;22(7):2607-16.

16. Jorgensen JM. On a possible hair cell turn-over in the inner ear of the caecilian Ichthyophis glutinosus. Acta Zool. 1981;62:171-86.

17. Jorgensen JM. Regeneration of lateral line and inner ear vestibular cells. Ciba Found Symp. 1991;160:151-63, discussion 163-70.

18. Raphael Y. Evidence for supporting cell mitosis in response to acoustic trauma in the avian inner ear. J Neurocytol. 1992;21(9):663-71.

19. Roberson DF, Weisleder P, Bohrer PS, Rubel EW. Ongoing production of sensory cells in the vestibular epithelium of the chick. Hear Res. 1992;57(2):166-74.

20. Stone JS, Cotanche DA. Synchronization of hair cell regeneration in the chick cochlea following noise damage. J Cell Sci. 1992;102(4):671-80.

21. Weisleder P, Rubel EW. Hair cell regeneration in the avian vestibular epithelium. Exp Neurol. 1992;115(1):2-6.

22. Oesterle EC, Tsue TT, Reh TA, Rubel EW. Hair-cell regeneration in organ cultures of the postnatal chicken inner ear. Hear Res. 1993;70(1):85-108.

23. Oesterle EC, Rubel EW. Postnatal production of supporting cells in the chick cochlea. Hear Res. 1993;66(2):213-24.

24. Raphael Y. Reorganization of the chick basilar papilla after acoustic trauma. J Comp Neurol. 1993;330(4):521-32.

25. Warchol ME, Corwin JT. Supporting cells in avian vestibular organs proliferate in serum-free culture. Hear Res. 1993; 71(1-2):28-36.

26. Weisleder P, Rubel EW. Hair cell regeneration after streptomycin toxicity in the avian vestibular epithelium. J Comp Neurol. 1993;331(1):97-110.

27. Stone JS, Cotanche DA. Identification of the timing of $S$ phase and the patterns of cell proliferation during hair cell regeneration in the chick cochlea. J Comp Neurol. 1994;341(1):50-67.

28. Tsue TT, Watling DL, Weisleder P, Coltrera MD, Rubel EW. Identification of hair cell progenitors and intermitotic migration of their nuclei in the normal and regenerating avian inner ear. J Neurosci. 1994;14(1):140-52.

29. Warchol ME. Supporting cells in isolated sensory epithelia of avian utricles proliferate in serum-free culture. Neuroreport. 1995;6(7):981-84.

30. Weisleder P, Tsue TT, Rubel EW. Hair cell replacement in avian vestibular epithelium: supporting cell to type I hair cell. Hear Res. 1995;82(1):125-33.

31. Jones JE, Corwin JT. Regeneration of sensory cells after laser ablation in the lateral line system: Hair cell lineage and macrophage behavior revealed by time-lapse video microscopy. J Neurosci. 1996;16(2):649-62.

32. Gleich O, Dooling RJ, Presson JC, Strutz J. Continuous proliferation of supporting cells and indications for hair cell differentiation in the inner ear of adult song birds with genetic cochlear hearing loss. HNO. 1996;44(6):307-12. German.

33. Baird RA, Steyger PS, Schuff NR. Mitotic and nonmitotic hair cell regeneration in the bullfrog vestibular otolith organs. Ann NY Acad Sci. 1996;781:59-70.

34. Stone JS, Leano SG, Baker LP, Rubel EW. Hair cell differentiation in chick cochlear epithelium after aminoglycoside toxicity: in vivo and in vitro observations. J Neurosci. 1996;16(19):6157-74.

35. Oesterle EC, Tsue TT, Rubel EW. Induction of cell proliferation in avian inner ear sensory epithelia by insulin-like growth factor-I and insulin. J Comp Neurol. 1997;380(2): 262-74.

36. Zheng JL, Helbig C, Gao WQ. Induction of cell proliferation by fibroblast and insulin-like growth factors in pure rat inner ear epithelial cell cultures. J Neurosci. 1997;17(1): 216-26.

37. Ding-Pfennigdorff D, Smolders JWT, Muller M, Klinke R. Hair cell loss and regeneration after severe acoustic overstimulation in the adult pigeon. Hear Res. 1998;120(1-2): $109-20$.

38. Stone JS, Choi YS, Woolley SM, Yamashita H, Rubel EW. Progenitor cell cycling during hair cell regeneration in the vestibular and auditory epithelia of the chick. J Neurocytol. 1999;28(10-11):863-76.

39. Wilkins HR, Presson JC, Popper AN. Proliferation of vertebrate inner ear supporting cells. J Neurobiol. 1999;39(4): 527-35.

40. Matsui JI, Oesterle EC, Stone JS, Rubel EW. Characterization of damage and regeneration in cultured avian utricles. J Assoc Res Otolaryngol. 2000;1(1):46-63.

41. Stone JS, Rubel EW. Temporal, spatial, and morphologic features of hair cell regeneration in the avian basilar papilla. J Comp Neurol. 2000;417(1):1-16.

42. Montcouquiol M, Corwin JT. Intracellular signals that control cell proliferation in mammalian balance epithelia: key roles for phosphatidylinositol-3 kinase, mammalian target of rapamycin, and S6 kinases in preference to calcium, protein kinase $\mathrm{C}$, and mitogen-activated protein kinase. J Neurosci. 2001;21(2):570-80.

43. Montcouquiol M, Corwin JT. Brief treatments with forskolin enhance s-phase entry in balance epithelia from the ears of rats. J Neurosci. 2001;21(3):974-82.

44. Warchol ME. Blocking the function of N-cadherin inhibits sensory regeneration in the avian inner ear. Association for Research in Otolaryngology 23rd Midwinter Research 
Meeting [abstract 4899]; 2000 Feb 23; St. Petersburg Beach, FL. Mt. Royal (NJ): ARO; 2000. p. 840.

45. Warchol ME, Matsui JI, Simkus EL, Ogilive JM. Ongoing cell death and immune influences on regeneration in the vestibular sensory organs. Ann NY Acad Sci. 2001; 942:34-45.

46. Witte MC, Montcouquiol M, Corwin JT. Regeneration in avian hair cell epithelia: Identification of intracellular signals required for S-phase entry. Eur J Neurosci. 2001; 14(5):829-38.

47. Matsui JI, Ogilvie JM, Warchol ME. Inhibition of caspases prevents ototoxic and ongoing hair cell death. J Neurosci. 2002;22(4):1218-27.

48. Harris JA, Cheng AG, Cunningham LL, MacDonald G, Raible DW, Rubel EW. Neomycin-induced hair cell death and rapid regeneration in the lateral line of zebrafish (Danio rerio). J Assoc Res Otolaryngol. 2003;4(2):219-34.

49. Murakami SL, Cunningham LL, Werner LA, Bauer E, Pujol R, Raible DW, Rubel EW. Developmental differences in susceptibility to neomycin-induced hair cell death in the lateral line neuromasts of zebrafish (Danio rerio). Hear Res. 2003;186(1-2):47-56.

50. Oesterle EC, Cunningham DE, Westrum LE, Rubel EW. Ultrastructural analysis of $[3 \mathrm{H}]$ thymidine-labeled cells in the rat utricular macula. J Comp Neurol. 2003;463(2): 177-95.

51. Adler HJ, Raphael Y. New hair cells arise from supporting cell conversion in the acoustically damaged chick inner ear. Neurosci Lett. 1996;205(1):17-20.

52. Roberson DW, Kreig CS, Rubel EW. Light microscopic evidence that direct transdifferentiation gives rise to new hair cells in regenerating avian auditory epithelium. Aud Neurosci. 1996;2:195-205.

53. Baird RA, Burton MD, Fashena DS, Naeger RA. Hair cell recovery in mitotically blocked cultures of the bullfrog saccule. Proc Natl Acad Sci US. 2000;97(22):11722-29.

54. Berggren D, Liu W, Frenz D, Van De Water T. Spontaneous hair-cell renewal following gentamicin exposure in postnatal rat utricular explants. Hear Res. 2003;180(1-2):114-25.

55. Roberson DW, Alosi JA, Cotanche DA. Direct transdifferentiation gives rise to the earliest new hair cells in regenerating avian auditory epithelium. J Neurosci Res. 2004;78(4):461-71.

56. Warchol ME. Macrophage activity in organ cultures of the avian cochlea-demonstration of a resident population and recruitment to sites of hair cell lesions. J Neurobiol. 1997;33(6):724-34.

57. Rappolee SA, Mark D, Banda MJ, Werb Z. Wound macrophages express TGF- $\alpha$ and other growth factors in vivo: analysis by mRNA phenotyping. Science. 1988;241:708-12.
58. Duvall E, Wyllie AH, Morris RG. Macrophage recognition of cells undergoing programmed cell death (apoptosis). Immunology. 1985;56(2):351-58.

59. Rappolee DA, Werb Z. Macrophage-derived growth factors. Curr Top Microbiol Immunol. 1992;181:87-140.

60. Balak KJ, Corwin JT, Jones JE. Regenerated hair cells can originate from supporting cell progeny: evidence from phototoxicity and laser ablation experiments in the lateral line system. J Neurosci. 1990;10(8):2502-12.

61. Fredelius L, Rask-Andersen H. The role of macrophages in the disposal of degeneration products within the organ of corti after acoustic overstimulation. Acta Otolaryngol. 1990;109(1-2):76-82.

62. Bhave SA, Oesterle EC, Coltrera MD. Macrophage and microglia-like cells in the avian inner ear. J Comp Neurol. 1998;398(2):241-56.

63. Warchol ME. Immune cytokines and dexamethasone influence sensory regeneration in the avian vestibular periphery. J Neurocytol. 1999;28(10-11):889-900.

64. Warchol ME, Kaplan BA. Macrophage secretory products influence the survival of statoacoustic neurons. Neuroreport. 1999;10(4):665-68.

65. O'Halloran EK, Oesterle EC. Characterization of leukocyte subtypes in chicken inner ear sensory epithelia. J Comp Neurol. 2004;475(3):340-60.

66. Raff M. Adult stem cell plasticity: fact or artifact? Annu Rev Cell Dev Biol. 2003;19:1-22.

67. Li H, Liu H, Heller S. Pluripotent stem cells from the adult mouse inner ear. Nat Med. 2003;9(10):1293-99.

68. Li H, Roblin G, Liu H, Heller S. Generation of hair cells by stepwise differentiation of embryonic stem cells. Proc Natl Acad Sci US. 2003;100(23):13495-500.

69. Tateya I, Nakagawa T, Iguchi F, Kim TS, Endo T, Yamada S, Kageyama R, Naito Y, Ito J. Fate of neural stem cells grafted into injured inner ears of mice. Neuroreport. 2003; 14(13):1677-81.

70. Chen P, Segil N. p27(Kip1) links cell proliferation to morphogenesis in the developing organ of Corti. Development. 1999;126(8):1581-90.

71. Lowenheim H, Furness DN, Kil J, Zinn C, Gultig K, Fero ML, Frost D, Gummer AW, Roberts JM, Rubel EW, Hackney CM, Zenner HP. Gene disruption of p27(Kip1) allows cell proliferation in the postnatal and adult organ of Corti. Proc Natl Acad Sci US. 1999;96(7):4084-88.

72. Bermingham NA, Hassan BA, Price SD, Vollrath MA, Ben-Arie N, Eatock RA, Bellen HJ, Lysakowski A, Zoghbi HY. Math1: an essential gene for the generation of inner ear hair cells. Science. 1999;284(5421):1837-41.

73. Woods C, Montcouquiol M, Kelley MW. Math1 regulates development of the sensory epithelium in the mammalian cochlea. Nat Neurosci. 2004;7(12):1310-18. 
74. Zheng JL, Gao WQ. Overexpression of Math1 induces robust production of extra hair cells in postnatal rat inner ears. Nat Neurosci. 2000;3(6):580-86.

75. Raphael Y, Frisancho JC, Roessler BJ. Adenoviral-mediated gene transfer into guinea pig cochlear cells in vivo. Neurosci Lett. 1996;207(2):137-41.

76. Dazert S, Battaglia A, Ryan AF. Transfection of neonatal rat cochlear cells in vitro with an adenovirus vector. Int $\mathrm{J}$ Dev Neurosci. 1997;15(4-5):595-600.

77. Dazert S, Aletsee C, Brors D, Gravel C, Sendtner M, Ryan A. In vivo adenoviral transduction of the neonatal rat cochlea and middle ear. Hear Res. 2001;151(1-2):30-40.

78. Holt JR, Johns DC, Wang S, Chen ZY, Dunn RJ, Marban E, Corey DP. Functional expression of exogenous proteins in mammalian sensory hair cells infected with adenoviral vectors. J Neurophysiol. 1999;81(4):1881-88.

79. Yagi M, Magal E, Sheng Z, Ang KA, Raphael Y. Hair cell protection from aminoglycoside ototoxicity by adenovirusmediated overexpression of glial cell line-derived neurotrophic factor. Hum Gene Ther. 1999;10(5):813-23.

80. Suzuki M, Yagi M, Brown JN, Miller AL, Miller JM, Raphael Y. Effect of transgenic GDNF expression on gentamicin-induced cochlear and vestibular toxicity. Gene Ther. 2000;7(12):1046-54.

81. Luebke AE, Steiger JD, Hodges BL, Amalfitano A. A modified adenovirus can transfect cochlear hair cells in vivo without compromising cochlear function. Gene Ther. 2001;8(10):789-94.

82. Staecker H, Li D, O’Malley BW Jr, Van De Water TR. Gene expression in the mammalian cochlea: a study of multiple vector systems. Acta Otolaryngol. 2001;121(2): 157-63.

83. Kanzaki S, Ogawa K, Camper SA, Raphael Y. Transgene expression in neonatal mouse inner ear explants mediated by first and advanced generation adenovirus vectors. Hear Res. 2002;169(1-2):112-20.

84. Kawamoto K, Kanzaki S, Yagi M, Stover T, Prieskorn DM, Dolan DF, Miller JM, Raphael Y. Gene-based therapy for inner ear disease. Noise Health. 2001;3(11):37-47.

85. Ishimoto S, Kawamoto K, Stover T, Kanzaki S, Yamasoba T, Raphael Y. A glucocorticoid reduces adverse effects of adenovirus vectors in the cochlea. Audiol Neurootol. 2003;8(2):70-79.

86. Ishimoto S, Kawamoto K, Kanzaki S, Raphael Y. Gene transfer into supporting cells of the organ of Corti. Hear Res. 2002;173(1-2):187-97.

87. Yamasoba T, Suzuki M, Kondo K. Transgene expression in mature guinea pig cochlear cells in vitro. Neurosci Lett. 2002;335(1):13-16.

88. Hakuba N, Watabe K, Hyodo J, Ohashi T, Eto Y, Taniguchi M, Yang L, Tanaka J, Hata R, Gyo K. Adenovirusmediated overexpression of a gene prevents hearing loss and progressive inner hair cell loss after transient cochlear ischemia in gerbils. Gene Ther. 2003;10(5):426-33.

89. Praetorius M, Baker K, Weich CM, Plinkert PK, Staecker $H$. Hearing preservation after inner ear gene therapy: the effect of vector and surgical approach. ORL J Otorhinolaryngol Relat Spec. 2003;65(4):211-14.

90. Luebke AE, Foster PK, Muller CD, Peel AL. Cochlear function and transgene expression in the guinea pig cochlea, using adenovirus- and adeno-associated virus-directed gene transfer. Hum Gene Ther. 2001;12(7):773-81.

91. Kawamoto K, Ishimoto S, Minoda R, Brough DE, Raphael Y. Math1 gene transfer generates new cochlear hair cells in mature guinea pigs in vivo. J Neurosci. 2003; 23(11):4395-400.

92. Doetzlhofer A, White PM, Johnson JE, Segil N, Groves AK. In vitro growth and differentiation of mammalian sensory hair cell progenitors: a requirement for EGF and periotic mesenchyme. Dev Biol. 2004;272(2):432-47.

93. Chen ZY. Applications of genomics in the inner ear. Pharmacogenomics. 2003;4(6):735-45.

94. Chen ZY, Corey DP. An inner ear gene expression database. J Assoc Res Otolaryngol. 2002;3(2):140-48.

95. Cho Y, Gong TW, Stover T, Lomax MI, Altschuler RA. Gene expression profiles of the rat cochlea, cochlear nucleus, and inferior colliculus. J Assoc Res Otolaryngol. 2002;3(1):54-67.

96. Rivolta MN, Halsall A, Johnson CM, Tones MA, Holley MC. Transcript profiling of functionally related groups of genes during conditional differentiation of a mammalian cochlear hair cell line. Genome Res. 2002;12(7):1091-99.

97. Hawkins RD, Bashiardes S, Helms CA, Hu L, Saccone NL, Warchol ME, Lovett M. Gene expression differences in quiescent versus regenerating hair cells of avian sensory epithelia: implications for human hearing and balance disorders. Hum Mol Genet. 2003;12(11):1261-72.

98. Jones TA, Nelson RC. Recovery of vestibular function following hair cell destruction by streptomycin. Hear Res. 1992;62(2):181-86.

99. Carey JP, Fuchs AF, Rubel EW. Hair cell regeneration and vestibulo-ocular reflex recovery. Ann NY Acad Sci. 1996;781:47-58.

100. Carey JP, Fuchs AF, Rubel EW. Hair cell regeneration and recovery of the vestibuloocular reflex in the avian vestibular system. J Neurophysiol. 1996;76(5): 3301-12.

101. Goode CT, Carey JP, Fuchs AF, Rubel EW. Recovery of the vestibulocolic reflex after aminoglycoside ototoxicity in domestic chickens. J Neurophysiol. 1999;81(3):1025-35.

102. Goode CT, Maney DL, Rubel EW, Fuchs AF. Visual influences on the development and recovery of the vestibuloocular reflex in the chicken. J Neurophysiol. 2001; 85(3):1119-28. 
103. Matsui JI, Haque A, Huss D, Messana EP, Alosi JA, Roberson DW, Cotanche DA, Dickman JD, Warchol ME. Caspase inhibitors promote vestibular hair cell survival and function after aminoglycoside treatment in vivo. J Neurosci. 2003;23(14):6111-22.

104. Jones SM, Ryals BM, Colbert S. Vestibular function in Belgian Waterslager canaries (Serinus canarius). Hear Res. 1998;121(1-2):161-69.

105. Dickman JD, Lim I. Posture, head stability, and orientation recovery during vestibular regeneration in pigeons. J Assoc Res Otolaryngol. 2004;5(3):323-36.

106. Dooling RJ, Ryals BM, Manabe K. Recovery of hearing and vocal behavior after hair-cell regeneration. Proc Natl Acad Sci US. 1997;94(25):14206-10.

107. Ryals BM, Dooling RJ. Discussion: changes in vocal production after hair cell regeneration. J Commun Disord. 2000;33(4):313-19.

108. Woolley SM, Rubel EW. Bengalese finches Lonchura Striata domestica depend upon auditory feedback for the maintenance of adult song. J Neurosci. 1997;17(16):6380-90.

109. Woolley SM, Wissman AM, Rubel EW. Hair cell regeneration and recovery of auditory thresholds following aminoglycoside ototoxicity in Bengalese finches. Hear Res. 2001;153(1-2):181-95.

110. Woolley SM, Rubel EW. Vocal memory and learning in adult Bengalese Finches with regenerated hair cells. J Neurosci. 2002;22(17):7774-87.
111. Woolley SM. Auditory experience and adult song plasticity. Ann NY Acad Sci. 2004;1016:208-21.

112. Woolley SM, Rubel EW. High-frequency auditory feedback is not required for adult song maintenance in Bengalese finches. J Neurosci. 1999;19(1):358-71.

113. Gleich O, Klump GM, Dooling RJ. Peripheral basis for the auditory deficit in Belgian Waterslager canaries (Serinus canarius). Hear Res. 1995;82(1):100-108.

114. Wilkins HR, Presson JC, Popper AN, Ryals BM, Dooling RJ. Hair cell death in a hearing-deficient canary. J Assoc Res Otolaryngol. 2001;2(1):79-86.

115. Gleich O, Dooling RJ, Ryals BM. A quantitative analysis of the nerve fibers in the VIIIth nerve of Belgian Waterslager canaries with a hereditary sensorineural hearing loss. Hear Res. 2001;151(1-2):141-48.

116. Kubke MF, Dent ML, Hodos W, Carr CE, Dooling RJ. Nucleus magnocellularis and nucleus laminaris in Belgian Waterslager and normal strain canaries. Hear Res. 2002; 164(1-2):19-28.

117. Cotanche DA. Structural recovery from sound and aminoglycoside damage in the avian cochlea. Audiol Neurootol. 1999;4(6):271-85.

118. Parker MA, Cotanche DA. The potential use of stem cells for cochlear repair. Audiol Neurootol. 2004;9(2):72-80.

Submitted for publication January 11, 2005. Accepted in revised form April 25, 2005. 